\title{
R. Moss
}

\section{BEYOND "TWO SOURCE THEORY” AND "SOLA SCRIPTURA": ECUMENICAL PERSPECTIVES ON SCRIPTURE AND TRADITION}

\begin{abstract}
A major source of doctrinal dispute between Catholicism and Protestantism over the centuries has revolved around the relationship between Scripture and Tradition. Does Scripture as the source of Revelation stand alone as in sola scriptura or does Scripture need to be interpreted and understood within the tradition from which it emerged and by which it should be understood. The Constitution, Dei Verbum, promulgated by the Second Vatican Council and the two Protestant Conferences held almost contemporaneously at Oberlin and Montreal suggest a possible convergence beyond the impasse. Protestantism needs to acknowledge the importance of tradition in biblical interpretation while Catholicism having effectively abandoned the two source theory of revelation needs criteria to distinguish between authentic tradition closely linked to scripture and an inauthentic tradition.
\end{abstract}

\section{INTRODUCTION}

Avery Dulles provides the thesis for which this paper will argue, that is, that both the standard pre- Vatican II Catholic two- source theory of revelation and the classical Protestant sola Scriptura position are untenable. Dulles argues:

Since Vatican II and Montreal there has been a growing ecumenical consensus to the effect that both the 'two-sources' theory of Counter- Reformation Catholicism and the sola Scriptura formula of reformation Protestantism are unsatisfactory. Against the former position it is argued that Scripture and tradition are not two distinct 
reservoirs, each containing a certain portion of revealed truth. Against the latter, it observed that Scripture is never really alone. The Christian reads it within the church in the light of the use the church makes of it (1980:25).

The Vatican II Dogmatic Constitution on Divine Revelation, Dei Verbum, took a firm position against the two-source theory of divine revelation. Contemporaneous with the debates on Dei Verbum, two Protestant conferences took place, one at Oberlin, Ohio (1963) and the other at Montreal (1963). The former was a Consultation for Church Unity and the latter the Fourth World Conference on Faith and Order of the World Council of Churches. Two reports were issued, "Scripture, Tradition and the Guardians of Tradition" (Oberlin) and "Scripture, Tradition and tradition" (Montreal).

In this paper I will first look to the earliest tradition of the Church, that of the Fathers, in order to discern their approach to the relationship between Scripture and Tradition. Two patristic scholars, Tertullian and Irenaeus will be considered. John Henry Newman, an eminent nineteenth century theologian and scholar of patristics will give a modern summary of the position. Next the relationship between Scripture and Tradition will be considered in the light of the Reformation sola scriptura principle. The origin of Trent's 'two-sources' theory will then lead into a consideration of the two remarkable conferences mentioned above, Oberon and Montreal, that sought to lead Protestant thought towards a reassessment of the classical sola scriptura of the Reformation period. The Second Vatican Council's dogmatic constitution Dei Verbum then leads the Catholic Church beyond the 'two source' theory of revelation. Finally the paper will assess the possible ecumenical implication of these significant developments.

\section{SCRIPTURE AND TRADITION IN THE EARLY CHURCH}

The Fathers of the Church considered tradition to be the faithful preservation and passing on of the Gospel from generation to generation of believers. It was always understood in concert with Scripture and secondarily involved the accepted practices of the church such as discipline and liturgy. Moreover, they believed that this saving Gospel could be understood clearly, faithfully and correctly across the generations. This gospel included as suggested above more than the apostolic canonical documents; it included also the practices and beliefs contained in the Church's rule of faith (regula fidei). William Abrahams expresses the relationship in these words:

We might sum up by thinking of the varied canonical traditions as different elements in the production of a grand symphony. The music 
which results is the music of salvation which naturally transposes itself into hymns of praise. Some of the canonical tradition, like the water, oil, bread, and wine of the sacraments, represents various instruments in the orchestra of the Church. Some like Fathers and bishops, represent various players. Some like liturgical material represent the scores, which are best followed according to the programme notes which accompany them. Everyone involved in the orchestra must approach his or her role in a spirit of humility and dependence, of joy and praise. Most important of all, everyone must heed and be open to the leading of the great conductor, the Holy Spirit, who, through the use of the canonical tradition of the Church, creates within the participants the melody of Christ the saviour, a music which leads ineluctably into the unfathomable, unspeakable mystery of the living God (2002:55).

Consequently, scriptural interpretation for maintaining correct doctrine based on the Bible alone (sola scriptura) was impossible. Tertullian felt it necessary to seek a prior principle. He states:

We must not appeal to Scripture... one point should be decided first, namely, who holds the truth to which the Bible belongs, and from whom, through whom, when and to whom was the teaching delivered by which men became Christian? For only where the true Christian teachings are evident, will the true Scriptures, the true interpretation, and all the true Christian tradition be found. 1

Tertullian is insisting that Scripture be handled only with reference to those fundamental teachings (the so-called regula fidei) found within and believed by the apostolic churches. These teachings were what may be regarded as the "canon" for orthodoxy. D.H. Williams expresses the idea in these words:

To be more precise, the regula did not function as a standard for the faith; it was a distillation of the tradition, synonymous with the apostolic faith (1998:354).

Tertullian certainly affirmed the pre-eminence of Scripture but as scriptural interpretation was often a bone of contention especially in the frequent confrontations with heretical groups, he declared that to abandon the regula for private interpretation of either Scripture or indeed doctrine was to depart from the Christian faith (On the prescription of Heretics, ANF 3). Scripture and Tradition belonged together and Scripture was an aspect of Christian Tradition and consequently agreed with it on the

1 Tertullian, On the Prescription of Heretics, 19 in Ante Nicene Fathers, 3. (hereafter ANF) 
particulars of Christian teaching or the regula (Against Marcion, 4.2 ANF3). Effectively Tertullian presented a reciprocal relationship between Scripture and Tradition. They were one gospel, one source of revelation. Tradition had no claims on the believer without scriptural support; Scripture, on the other hand, could not be used to justify doctrine unsupported by the Church's tradition.

Irenaeus, bishop of Lyon in the second century $A D$, too, is a clear exponent of the "grand symphony" expounded above. Against his Gnostic opponents he strongly asserted the authority of Scripture and the Church and her tradition. Various Gnostic teachers claimed to possess a secret divine authority for their particular doctrines and often taught that they had received secret revelations handed down to them by the apostles. Irenaeus writes:

They tell us, however, that this knowledge has not been openly divulged, because all are not capable of receiving it, but has been mystically revealed by the Saviour through means of parables to those qualified for understanding it.

Irenaeus (Against Heresies, 1.3.1 ANF 1.319) insists that there is no need to go beyond the apostles in search of additional revelation. As he sees the position, the apostles possessed

perfect knowledge.... For, after our Lord rose from the dead, the apostles were invested with power from on high when the Holy Spirit came down upon them, were filled with his gifts, and had perfect knowledge.

Irenaeus understood the situation such that revelation to the apostles was intimately linked to the Holy Spirit and divinely inspired in such a way that apostolic testimony was the Word of God. Further, Irenaeus would not separate the authority of Scripture and the task of biblical interpretation from the community of the church itself. The Gnostic error, for Irenaeus, lay in their failure to join themselves to the Church. Irenaeus explains:

...this gift of God has been entrusted to the Church, as breath was to the first created man, for this purpose, that all the members receiving it may be vivified; and the [means of ] communion with Christ has been distributed throughout it, that is, the Holy Spirit ... the means of confirming our faith, and the ladder of ascent to God (3.24.1 ANF 1.458).

Irenaeus is convinced that because the Gnostics deserted the church in their quest for "knowledge", they have forfeited the spirit and the life of Christ. "For where the church is, there is the Spirit of God; and where the Spirit of God, there is the Church ...." (3.22 ANF 1.415) It is then within the 
church that the traditions (the teachings of the apostles) have been faithfully preserved and passed on rather than within the Gnostic communities.

It is within the power of all, therefore, in every Church, who may wish to see the truth, to contemplate clearly the tradition of the apostles manifested throughout the whole world; and we are in a position to reckon up those who were by the apostles instituted in the Churches and [to demonstrate] the success of these men to our own times (3.3.1 ANF 1.415).

The apostolic tradition flowed from the apostolic teaching and had been handed down publicly by them in their writings to specific Christian leaders who in turn were to pass it on and preserve that same truth faithfully. Whatever the church chooses to say must then find its roots in the apostolic tradition. The Gnostics, however, refused to submit to apostolic doctrine as taught in the Scriptures and preserved by the Church. Gnostic doctrine itself is confused and "scattered here and there without agreement or connection" (5.20.1 ANF 1.548). The remedy for this willful blindness is to run "to the Church... be brought up in her bosom, and be nourished with the Lord's Scriptures" (5.20.2 ANF 1.548).

In this section we have noted how at an early period in the history of the Church, Irenaeus testifies that the content of the apostolic tradition was already identifiable and Scriptural interpretation was bound to the community of the Church itself. Failure to read Scripture well on the part of the Gnostics arose from their failure to join themselves to the Church where the Spirit is.

A more modern rendering of the above themes was undertaken by John Henry Newman, the so-called father of the Second Vatican Council. Newman asserts that scriptural interpretation requires the guidance and assistance of the Church Fathers.

I will go further, not only is the context insufficient for the interpretation of scriptural terms and phrases, but a right knowledge of these [the Fathers] is necessary for interpreting that context (Newman in Barbeau 2002).

It is to the regula and the Fathers that biblical exegesis must turn for the text alone can often yield contradictory interpretation due to a focus on what Newman would term the level of sign alone (Newman in Barbeau 2002). If one is to be guided by the biblical context alone, according to Newman, words may signify many things. The words of scripture are best interpreted by patristic reference. 
If no word is to be taken to mean more than its logical definition, we shall never get beyond abstract knowledge, for it cannot carry its own explanation with it. They who wish to dispense with antiquity, should, in consistency, go further, and attempt to learn a language without a dictionary. ${ }^{2}$

In conclusion then it can be said that the meanings of Scripture are not on the surface as it were- they require an interpretation through the lens of the early church. Sola scriptura is not a feasible option-

all those who try to go by scripture only, fall away from the church and her doctrines, to one or other sect or party, as if showing that whatever is or is not scriptural, at least the church, by consent of all men, is not so. ${ }^{3}$

The Reformation contention that Scripture can stand independent of the ancient consensus of the Church's faith, that it is self-interpreting will be addressed next.

\section{SCRIPTURE AND TRADITION AND THE REFORMATION}

The relationship between Scripture and Tradition in the Protestant tradition is an unhappy one. Tradition is regarded primarily in a negative sense and normally refers to observances instituted by corrupt ecclesial authorities in order to gain God's grace. In the Book of Concord for example there is no understanding of tradition as involving the process of the handing on of the Gospel and the relationship of this process to the creeds and teaching of the church. Article 15 of the Augsburg Confession, for example, states:

Moreover it is taught among us that all ordinances and traditions made by human beings for the purpose of appeasing God and earning grace are contrary to the gospel and teaching about faith in Christ (Tappert 1959:36-37).

2 Ibid., 123. It should be noted that the Lectures on Justification argue, at least implicitly, against the shortcomings of the historical method, whereas the later Tract 85 uses modern methodology as the basis for Newman's argumentation. However, he would still regard the 'dictionary' of the Fathers as necessary for correct biblical exegesis. Thus tradition is necessary for orthodox biblical exegesis.

3 Newman, J.H., 'Tracts for the Times', 85,2 quoted in Barbeau, J.W., 'Newman and the Interpretation of Inspired Scripture', 57 
Here there does not seem to be an understanding of tradition involving the transmission of the gospel and its relationship to the authoritative teaching of the church. Indeed, there is an assumption on the part of some in the Protestant tradition that tradition is totally a human product of the church used to impose the authority of the church.

Although the Reformers laid great value on the church fathers, I contend that they often failed to understand them on their own terms and within their own specific historical context. D.H. Williams contends though, correctly in my estimation, that

[i]n no way did Luther or Calvin reject the authority of tradition, although it had to be regulated by scripture. Indeed, their knowledge of the early fathers was the inspiration for their conviction (1998:357).

However, as we noted in section 2, the Fathers of the second to fifth centuries such as Irenaeus and Tertullian would have found that appeal to Scripture alone for maintaining pure doctrine was impossible. There needed, for example, for Tertullian to be a "prior principle". Scripture could not be correctly interpreted without reference to the foundational teachings or the "rule of faith" that resided within the apostolic churches. Augustine, too, contends that "the rule of faith" is necessary when interpreting scripture. It is through an appeal to the doctrinal tradition already existing that the church is able to make a proper and correct interpretation of the Bible. ${ }^{4}$

Sola Scriptura then, as a hermeneutical principle is problematic as scripture can never stand completely independent of the ancient consensus of the church's teaching. In effect sola scriptura, the self-interpretation of the Bible, may have value for the most immediate aspects of Scripture. But Scripture divorced from reference to the historic tradition of the church is often subject to one's specific individual and group ideological and religious context.

A balanced understanding of the relationship between scripture and tradition is essential to new understanding between Catholics and Protestants. But did the Council of Trent provide this balanced understanding?

\section{TRENT AND TRADITION}

Trent is the attributed origin of the so-called "two-source" theory of revelation where Scripture and Tradition are seen as two parallel, yet complementary sources of divine revelation. Although this theory was

4 See: Augustine, On the Definition of the Nicene Creed, 20 quoted from Williams, D.H., "The search for Sola Scriptura in the early church", p. 361. 
already controversial, the draft schema as prepared for the first session of the Second Vatican Council was entitled De Fontibus Revelationis (On the Sources of Revelation) and accepted the "two-source" theory. ${ }^{5}$ This theory had been based on an erroneous interpretation of the Council of Trent's Decree on Sacred Books and on Traditions (8 April 1546). In order to challenge the Protestant principle of sola scriptura Trent stated, in reference to revelation, that it

\begin{abstract}
Clearly perceives that this truth and rule are contained in written books and in unwritten traditions which were received by the apostles from the mouth of Christ himself or else have come down to us, handed on as it were from the apostles themselves at the inspiration of the Holy Spirit. ${ }^{6}$
\end{abstract}

An earlier draft of the above text had stated that revelation was contained "partly in written books, partly in unwritten traditions". A minority objected to the words "partly... partly" as this would seem to suggest two quasi-independent sources of revelation. Their objections were sustained and the text was changed to read as above "in written books and unwritten traditions." Effectively now there is one source with two means by which the one source of saving truth, the Gospel is made available to the ecclesial community (Mullins 2005:408-409). This interpretation concurs with the teaching promulgated in the Constitution Dei Verbum as outlined in section 6 below. However, teaching subsequent to Trent was interpreted in light of the "partly...partly" understanding. It would take Vatican II to correct this "misconception" and to develop further the "true" teaching of Trent. But before considering Dei Verbum two dramatic Protestant initiatives will be considered.

\title{
5. OBERLIN AND MONTREAL ON TRADITION
}

At about the time of the intense debates at the Second Vatican Council concerning the Constitution on scripture that would eventually be known

5 The first chapter of this schema was called "The Double Source of Revelation" and it stated that "holy mother church always believed and believes that the whole revelation is contained, not in Scripture alone, but in Scripture and Tradition as a double source, each, nevertheless, according to its own manner." See Francisco Gil Hellin, Constitutio dogmatica de divina revelation Dei Verbum, Concilii Vatican II synopsis in ordinem redigens schemata cure relationibus nec non partum orations atque anima adversiones, 1993, Vatican City: Libreria Editrice Vaticana, p.182

6 The General Council of Trent, Fourth Session, Tradition and Scripture as Sources of Faith, 1501. 
as Dei Verbum, two remarkable Protestant conferences took place which dealt with themes analogous to those being debated in Rome, that is, Scripture, Tradition and the Magisterium. The first of the conferences was the Oberlin Meeting on the Consultation on Church Union in March 1963. The second was the Fourth World Conference on Faith and Order held at Montreal in July 1963 where the work of the second section was entitled Scripture, Tradition and traditions.

The Oberlin Meeting issued three reports the longest entitled Scripture, Tradition and the Guardians of Tradition. This report consisted of four sections: scripture, tradition, the relationship between scripture and tradition and finally the guardianship of the apostolic testimony of the whole church. The Report affirms the common understanding of the Reformation principle of sola Scriptura in a confession of both the centrality of Christ and the normativity of scripture in terms of Christian revelation:

Jesus Christ, crucified and rise, the living Lord and Head of the Church, is the centre of the Holy Scriptures.....because we confess Christ alone (solus Christus), in this way we affirm Scripture alone (sola Scriptura). The churches represented in this Consultation affirm the Holy Scriptures to be canonical, that is, the norm of their total life, including worship and witness and teaching and mission (COCU 1996:part 1).

Further, in the next section the Report, almost in parallel with Dei Verbum, in a significant way moves from the historical negativity associated with the corrupting influence of tradition in Christian life and worship. It notes, that it is

increasingly clear that Tradition cannot simply be equated with 'the traditions of men', teachings and practices which obscure or corrupt rather than express the revelation to which the Scriptures witness. By Tradition we understand the whole life of the Church, ever guided and nourished by the Holy Spirit, and expressed in its worship, witness, way of life, and its order. As such, tradition includes both the act of delivery by which the good news is made known and transmitted from one generation to another as well as the teaching and practice handed on from one generation to another (COCU 1996:part 2).

In the third section of the Report on the relation between Scripture and Tradition three relations are mentioned: Scripture itself is included in the Tradition, Tradition is an interpretive tool for scripture and finally that Scripture is the guardian and written determining expression of Tradition: 
... the Christian Tradition antedated the formation of the New Testament canon. The New Testament canon appears not as separate from or opposed to the Christian Tradition but rather as an expression of it. Certainly it is the case that in the Church, Scripture and Tradition are found together (COCU 1996:part 3).

All these points feature prominently in the promulgated version of Dei Verbum and will be addressed in the next section.

The fourth section of the Report addresses the ecclesial guardianship of the apostolic testimony and faith under the scriptures as the fundamental guardian. Thus

[T]he Church acknowledges its responsibility for its continuing guardianship of the apostolic testimony of God's act of reconciliation in Jesus Christ. For that guardianship, the whole Church is responsible. The Scriptures, illuminated by the Spirit in the Church, are the fundamental guardian as they are the source of life and light (COCU 1996:part 4).

Next attention will turn to the Montreal Conference and the second section from the conference on Scripture, Tradition and traditions. It is this section of the document that received the full approval of the Conference. Here it is clearly stated that the interpretation of Scripture must be guided and supported by the Tradition that shaped Scripture. ${ }^{7}$ This Tradition should continue to shape interpretation of Scripture. ${ }^{8}$ However, this authentic Gospel Tradition has to be distinguished from the merely human traditions arising in different contexts throughout Christian history. ${ }^{9}$

Avery Dulles suggests that that Oberlin's cautious recognition of the role of the Church as Guardians of Tradition in relation to Scripture and Tradition, and Montreal's recognition that the correct interpretation of

7 "The oral and written tradition of the prophets under the guidance of the Holy Spirit led to the formation of the Scriptures and to the canonization of the Old and New Testaments as the Bible of the Church. T[hat t]he very fact of Tradition precedes the Scriptures points to the significance of tradition, but also to the Bible as the treasure of the Word of God" (Rodger \& Vischer. 1963: Paper 42, n. 42).

8 "What is transmitted in the process of tradition is the Christian faith, not only as a sum of tenets, but as a living reality transmitted through the operation of the Holy Spirit. We can speak of the Christian Tradition (with a capital T), whose content is God's revelation and self-giving in Christ, present in the life of the Church." Ibid., nn. 46-47.

9 "How can we distinguish between traditions embodying the true Tradition and merely human traditions? Where do we find the genuine Tradition, and where impoverished tradition or even distortion of tradition?" Ibid., n.48. 
scripture lacks agreed determinative criteria may have had an influence on the Catholic Church in helping to clarify terminology in the drafting of Dei Verbum (Dulles 2002:184). Sacred Tradition and sacred scripture were now to be seen to make up a single deposit of the Gospel or the Word of God which is entrusted to the Church.

\section{DEI VERBUM ON SCRIPTURE AND TRADITION}

Dei Verbum certainly calls for an ecclesial reading of scripture: a scholarly reading of the text by the historical critical method on the one hand, and a faith reading on the other hand. Scripture is to be read in the same Spirit by which Scripture was written. The constitution effectively gives the following rules for a Catholic interpretation of Scripture: interpretation must be based on the whole Bible and the particular relationship between the Old and New Testaments; the living tradition of the Church will provide the diverse contexts in which scripture has been received and interpreted and which collectively hold value for the contemporary church; and finally interpretation must be guided by the whole of the church's teachings which are the result of past readings of scripture. In the ongoing work of scriptural interpretation the Holy Spirit is at work giving deeper insights into revelation within the living tradition of the church. This deeper insight takes place through the contemplative inner spiritual understanding of the whole People of God, the work of biblical and theological scholars and the watchful guidance of the magisterium. How then does Dei Verbum see tradition? Joseph Ratzinger says that the Constitution sees tradition as

the multi-layered yet one presence of the mystery of Christ in the world.... Teaching, life and worship are named as the three ways in which tradition is handed on (Ratzinger 1969:184).

There is a dynamic character to tradition. This tradition begins with the apostolic witness and through the assistance of the Holy Spirit there is a growth in the understanding of the words and realities handed down in the Church community (Dei Verbum 1984:8). The Christ event cannot thus be limited to the age of the historical Jesus, for through the fuller insights of this dynamic tradition the church is able to apply and understand her deeper significance, and make the application of her witness to the present event.

What then were the major issues clarified through the Constitution? Revelation was no longer a communication with reference to truth; rather, it is primarily God's own self-communication (Dei Verbum 1984:2). Tradition itself is defined broadly in accord with ancient practice. "The Church, in her 
teaching, life and worship, perpetuates and hands on to all generations, all that she believes" (Dei Verbum 1984:8) Dei Verbum stresses, too, the unity of Tradition and Scripture and opposes any attempt at separation (Dei Verbum 1984:9). Both form one deposit of the Word of God which is committed to the Church (Dei Verbum 1984:10).

There are three rules for a Catholic interpretation of scripture according to Ormond Rush:

\begin{abstract}
The interpreter should keep in mind the whole of the bible and the relationship between the New and Old Testament. Then, the interpreter must attend to the living tradition of the church down through the centuries and the diverse ways in which scripture has been received from diverse contexts. And, finally, the interpreter is to attend to the whole of the church's teachings which have been officially interpreted in the light of past readings of Scripture (Rush 2006:410).
\end{abstract}

There are also three ways in which according to Dei Verbum the Holy Spirit is at work in the ongoing process of the interpretation of revelation: the faithful's contemporary experience of salvation, theological scholarship and the magisterium of the Church (Dei Verbum 1984:8).

Ratzinger addresses a problem not considered by Dei Verbum but which is a close concern to Protestantism: how to distinguish legitimate tradition from what may be termed "distorting tradition". Ratzinger comments:

There is a distorting, as well as legitimate tradition.... Consequently, tradition must not be considered only affirmatively, but also critically....

(Ratzinger 1969:185). He raises a critical concern when he further notes that

we have to acknowledge the truth of the criticism that there is, in fact no explicit mention of the possibility of a distorting criticism and the place of scripture as an element in the Church that is also critical of tradition.... (Ratzinger 1969:193).

Ratzinger further contends that this concern of his involves the question of the ecclesia semper reformanda and omission will have unfortunate consequences (1969:193).

The ecclesial nature of the Word of God is not simply a question involving the teaching office but concerns the whole community of the faithful. It should be noted that Dei Verbum is the first text of the teaching office of the Church that places the teaching office of the Church under the 
authority of the Word of God. However, there is a reciprocal and indeed inseparable relationship of Scripture, tradition and the Church's teaching office, none of which can be conceived independently and in isolation from the others. Ratzinger sums the position in these words:

It is true that Scripture simply cannot be conceived separately from tradition, nor tradition separately from the Church, nor the latter separately from either of the other two, without the specific function of these three entities being thereby called into question (Ratzinger 1969:197-198).

However, Ratzinger stresses, a point essential for ecumenical sensitivities: scripture alone is defined as the Word of God:

only Scripture is defined in terms of what it is...Tradition, however, is described only functionally, in terms of what it does: it hands on the Word of God, but it is not the Word of God (1969:194).

In concluding this section it could be said that Dei Verbum steers a path between two extremes in the interpretation of scripture: biblical fundamentalism on the one hand and secular rationalism on the other hand. It clearly teaches that the human authors are divinely inspired and that their writings have an inerrant quality. ${ }^{10} \mathrm{In}$ response to modern rationalism, the work of biblical scholars, linguistic experts, history, archaeology and other fields is acknowledged (Dei Verbum 1984:12). The Catholic approach denies sola Scriptura, that is, that Scripture interprets itself: it needs the scientific approach and the perspective of faith within the context of the Tradition of the Church subject, as Dei Verbum notes,

to the judgment of the church which exercises the divinely conferred commission and ministry of watching over and interpreting the Word of God (Dei Verbum 1984:12)

\section{CONCLUSION}

Ecumenical discussion has led or is leading the Christian Church as a whole beyond the polarities of sola Scriptura and the "two-source" theory. Both positions resulting from the Reformation crisis of the sixteenth century were untenable. Indeed, as Dulles argues

10 "[T]he books of Scripture, firmly, faithfully and without error, teach that truth which God, for the sake of salvation, wished to be confided to the sacred Scriptures", Dei Verbum, 11. 
[s]ince Vatican II and Montreal there has been a growing ecumenical consensus to the effect that both the 'two-sources' theory of Counter Reformation Catholicism and the sola Scriptura formula of reformation Protestantism are unsatisfactory. Against the former position it is argued that Scripture and Tradition are not two distinct reservoirs, each containing a certain potion of revealed truth. Against the latter, it is observed that Scripture is never really alone. The Christian reads it within the church, in the light of the use the church makes of it (Dulles 1980:25).

The two documents from Oberlin and Montreal have contributed significantly to ecumenical convergence. They do not overcome all Catholic/ Protestant disputes about Scripture but do show a growing tendency on the part of Protestants to recognize that tradition has a part to play in the interpretation of Scripture. However, there was no agreed criterion for an agreed correct interpretation of Scripture. Ratzinger's position on the need to distinguish authentic tradition from inauthentic tradition was noted in the previous section and the ecumenical significance of his position should not be underestimated. Montreal too had acknowledged that tradition preceded the Scriptures and so pointed to tradition's significance. Scripture's interpretation then should not be divorced from the tradition that shaped it. Avery Dulles had noted that the Montreal document

left unresolved the question of how the Bible can judge tradition if its right interpretation depends, in part, upon tradition (Dulles 1980: 17).

Oberlin implied some kind of relationship between Scripture, tradition and Church authority. While not obviously recognizing an infallible Magisterium it did, however, recognize the whole Church as exercising the guardianship of the apostolic testimony or deposit. There is a fairly remarkable convergence on significant points. For example, Oberlin's use of Scripture, Tradition and the Guardians of Tradition can be matched by Dei Verbum's triad of Scripture, Tradition and Magisterium.

Tradition in both documents and in Dei Verbum recognise that tradition is intrinsic to the entire integral life of the church and is an ongoing process of "handing on". Montreal, for example, understood that "the Tradition" (with a capital T) referred to the transmission of the Gospel from generation to generation by the community of the Church. Tradition (with a $t$ in lower case) referred to the process of the "handing on" of tradition.

It is now fifty years since Dei Verbum, Oberlin and Montreal. Energies need to be focused more intently now on working towards a greater consensus. Perhaps we need to recognize a wider sense of tradition: there are various ways in which the Spirit who inspired the scriptures hands 
on God's self-communication from generation to generation and various criteria for the correct interpretation of the Scriptures by the Church. Ecumenical consensus may recognize the legitimate forms of diversity within the life and tradition of the Church.

\section{BIBLIOGRAPHY}

Augustine OF Hippo

1998. On the Definition of the Nicene Creed. In: Williams, D.H. 'The search for Sola Scriptura in the early church.' Interpretation 52(4):354- 367.

Aвraham, W.J.

2002. Canon and criterion in Christian theology. New York: Oxford University Press.

Alberigo, G \& Komonchak, J.A. (eds.)

1997. History of Vatican 11, Vols. II \&V. Maryknoll: Orbis/ Leuven: Peeters.

AYres, L.

2008. The soul and the reading of scripture: A note on Henri De Lubac. Scottish Journal of Theology 61(2):172-191.

BARBEAU, J.W.

2002. Newman and the interpretation of inspired Scripture. Theological Studies 63(1):53- 68.

Cocu.

1996. The official reports of the four meetings of the consultation. Cincinnati: Forward Movement.

Colson, C. \& Neuhaus, R. (eds.).

2002. Your Word is truth. Grand Rapids: Eerdmans.

Del Verbum.

1984. Dogmatic Constitution on Divine Revelation, 18 November, 1965. In: A. Flannery, (ed.), Vatican 11 The Conciliar and Post-Conciliar Documents. Collegeville: The Liturgical Press.

Dulles, A.

1980. Scripture: Recent protestant and Catholic views. Theology Today 37(1):7- 25.

2002. Revelation, Scripture and tradition. In: C. Colson \& R. Neuhaus (eds). Your Word is truth. (Grand Rapids: Eerdmans), pp. 35-58.

GiBBS, L.W.

2002. Richard Hooker's via media doctrine of Scripture and tradition. Harvard Theological Review 95(2):227-235. 
IRENAEUS,

1994. Against Heresies. In A. Roberts ( ed.), Ante-Nicene Fathers. Vol 1. (Peabody, MA: Hendrickson Publishers).

Mullins, $\mathrm{P}$.

The ecumenical movement and the transmission of the Word of God in Vatican II's Dei Verbum. The Ecumenical Review 57(4):406- 433.

Pearce, F.

2009. Scripture, tradition and authoritative teaching: a Lutheran response to a Catholic invitation. Lutheran Theological Journal 43(3):178- 187.

RATZINGER, J.

1969. Origin and Background. In: H. Vorgrimler (ed.), Commentary on the documents of Vatican 11 ,Volume III, (New York: Herder and Herder \& Burns \& Oates: London), pp. 184-194.

RodgeR, E.C. \& VISCHER, L. (EDS.)

1963. The fourth world conference on faith and order. London: SCM Press.

Rush, O.

2006. Dei Verbum forty years on: Revelation, inspiration and the Spirit. The Australian Catholic Record 83(4):406- 414.

TAPPERT, T.G. (TRANSLATOR \& EDITOR)

1959. The book of Concord: the confessions of the evangelical Lutheran church. Philadelphia: Fortress Press.

TERTULLIAN.

1994a. On the prescription of Heretics. In: A. Roberts (ed.) Ante-Nicene Fathers. Vol 3. (Peabody, MA: Hendrickson Publishers).

1994b. Against Marcion. In: A. Roberts (ed.) Ante-Nicene Fathers. Vol 3. Peabody, MA: Hendrickson Publishers.

WICKS, J.

2010. Vatican II on Revelation - from behind the Scenes. Theological Studies 71(3):637-650.

WiLliams, D.H.

1998. The search for Sola Scriptura in the early church. Interpretation 52(4):354- 367.

Keywords

Dei Verbum

Regula fidei

Sola scriptura

Tradition

Two source theory
Sleutelwoorde

Dei Verbum

Regula fidei

Sola scriptura

Tradisie

Twee-bron teorie 